\title{
Does thermal time for germination vary among populations of a tree legume (Peltophorum dubium)?
}

\author{
L. F. D. Andrade ${ }^{a *}$ and V. J. M. Cardoso ${ }^{a}$ \\ aDepartamento de Botânica, Instituto de Biociências, Universidade Estadual Paulista - UNESP, \\ Av. 24-A, 1515, CEP 13506-900, Rio Claro, SP, Brazil \\ *e-mail: luipedaibes@gmail.com
}

Received: September 9, 2014 - Accepted: April 17, 2015 - Distributed: August 31, 2016

(With 3 figures)

\begin{abstract}
Few works report the use of degree-days (DD) - used in crops to predict events and schedule management activities - to describe the germination of tropical trees. The cardinal temperatures (base, optimum and ceiling temperature) for germination of the species may vary depending on the seed provenance. Peltophorum dubium (Spreng.) Taub. is an early successional leguminous tree widely distributed in South America, often occurring as cultivated or naturalized trees, thus considered to be a good example for testing DD model in tree species. The main objective of this study was to describe the seed germination response of different populations of $P$. dubium as function of DD accumulation during germination assays in semi-controlled (fluctuating temperatures) conditions. Germination assays with manually scarified seeds sown in aluminum sheet trays filled with a composed substrate were performed under greenhouse conditions at different times. Three methods were employed in order to describe the accumulation of thermal time throughout the assays and, considering the seed lot and sowing time, a trapezoid area method was relatively more effective in describing the germination. The germination curves of $P$. dubium seeds from different populations, expressed in degree-days estimated directly from temperature records schedules, tend to be more clustered suggesting little variation among thermal time requirements in different seed provenances. Otherwise, the thermal time requirement can vary depending on the time of sowing, and any increase in DD requirement when the assays were performed under higher mean temperatures can be related to a thermal effect on the germination of scarified seeds.
\end{abstract}

Keywords: degree-day, Fabaceae (Leguminosae), seed, canafístula.

\section{O tempo térmico para germinação varia entre populações de uma leguminosa arbórea (Peltophorum dubium)?}

\section{Resumo}

O uso de graus-dia - utilizado em espécies cultivadas para predizer eventos e planejar ações de manejo - é reportado em poucos trabalhos para descrever a germinação de árvores tropicais. As temperaturas cardeais (base, ótima e teto) para germinação de uma espécie pode variar de acordo com a procedência das sementes. Peltophorum dubium (Spreng.) Taub. é uma leguminosa arbórea de sucessão inicial amplamente distribuída na América do Sul, podendo ocorrer como espécie cultivada ou naturalizada, sendo considerada um bom exemplo para testar modelos de graus-dia em espécie arbórea. O principal objetivo deste estudo foi descrever a resposta da germinação das sementes de diferentes populações de $P$. dubium como função do acúmulo de graus-dia durante ensaios em condições semi-controladas (flutuação térmica). Testes de germinação com sementes escarificadas manualmente e semeadas em bandejas de alumínio contendo substrato foram realizados sob condições de casa de vegetação em diferentes épocas do ano. Três métodos foram utilizados para descrever o acúmulo de tempo térmico nos ensaios e, considerando o lote das sementes e a época da semeadura, o método da área do trapézio foi relativamente mais eficaz em descrever a germinação. As curvas de germinação de sementes de $P$. dubium provenientes de diferentes populações, expressas em graus-dia estimados diretamente por meio do registro programado das temperaturas, tendem a ser mais agrupadas sugerindo pouca variação no requerimento de tempo térmico entre as diferentes procedências das sementes. Por outro lado, o requisito de tempo térmico pode variar de acordo com a época de semeadura e um incremento nos graus-dia exigidos quando os ensaios foram realizados sob temperaturas médias mais elevadas pode estar relacionado e um efeito térmico na germinação de sementes escarificadas.

Palavras-chave: graus-dia, Fabaceae (Leguminosae), semente, canafístula. 


\section{Introduction}

Temperature is the most important environmental factor regulating seed germination, when there is a reasonable water supply. Environmental mean temperatures are known to predict plant (including seed) traits in many species worldwide (Moles et al., 2014). Germination responses to temperature can be characterized by cardinal temperatures, that are the minimum or base ( $\mathrm{Tb}$ ), the optimum (To), and maximum or ceiling ( $\mathrm{Tc}$ ), with $\mathrm{Tb}$ and $\mathrm{Tc}$ being the lowest and highest temperatures, respectively, at which a given percentage of seed can germinate (Alvarado and Bradford, 2002). Between these extremes (Tb and Tc), temperature primarily influences the germination rate (i.e. reciprocal of the time taken for radicle emergence to occur), and for many species this rate increases linearly between $\mathrm{Tb}$ and To, then decreases also linearly between To and Tc. Such germination rate dependency on temperature is one of the most important factors controlling the emergence timing of a seed (Bewley et al., 2013; Simão et al., 2010). Thus, germination, as well as any stage of plant development, can occur only between the lower and upper thresholds, and seed response to that temperature interval can be used to "correct" the calendar days required for a plant (or a seed) to develop from one point to another in its life cycle. Such corrected time is commonly referred to as "thermal time", or "heat units", and basically it is the accumulated product of time and the difference between actual temperature (T) and $\mathrm{Tb}$ for each day (or hour), calculated in degree-days or degree-hours units (UC-IPM, 2014).

In general, the degree-days (DD) are calculated by adding each day's maximum (TM) and minimum (Tm) temperatures throughout the growing season (or time of assay), then that sum is divided by two to get a median (M) and, finally, the $\mathrm{Tb}$ value is subtracted from M (Miller et al., 2001). Alternatively, DD can be estimated by a record of hourly temperatures, rather than minimum and maximum $\mathrm{T}$, which are averaged to get a mean temperature. According to UC-IPM (2014) the latter method is more accurate than former for estimating DD accumulation. Each non dormant seed requires a determined amount of DD to complete its germination, thus the accumulated DD from a $\mathrm{Tb}$ can help predict when a given percent of the seed population will germinate. In other words, DD can give a good estimate of the time to emergence for specific crops based upon expected soil temperatures following planting (Bradford, 2002). The starting point (Tb) to accumulate DD varies with the species and/or seed batch and, moreover, season and climatic region can cause the DD calculation methods to vary in how accurately they describe actual DD (UC-IPM, 2014).

Peltophorum dubium (Spreng.) Taub. var. dubium (Fabaceae, Caesalpinioideae) is a leguminous tree widely distributed in South America, naturally dispersed from Bahia to the Paraguai-Paraná basin, often occurring as cultivated or naturalized trees (see Barneby, 1996). The species has characteristics of early successional, like the frequent production of small seeds and fast growth, potentially serving as model for ecophysiological analyses and thermal approaches to forest seeds germination. As reported by Alves et al. (2011) and Oliveira et al. (2008), a temperature of $30^{\circ} \mathrm{C}$ is recommended for germination test with $P$. dubium seeds, whereas Andrade (2013), working with $P$. dubium seeds from four different populations, demonstrated that the optimum temperature for germination of the species, as well as cardinal temperatures, can vary slightly depending on the seed provenance.

Degree-days are commonly used in crops to predict events and schedule management activities, but few works (e.g. Lamarca et al., 2011, 2013) report its use in tropical trees. Moreover, most the studies using thermal time as descriptor of plant development stages as influenced by temperature (Trentin et al., 2008) lack to validate the model by comparing the records with model predictions, i.e. comparing the growth stage calculation using calendar days and degree-days. This study basically had two goals: (a) to relate seed germination response of different populations of P. dubium with degree-days accumulation, in greenhouse conditions, under fluctuating temperatures and; (b) to compare different degree-days calculation methods in order to find which one best describes the germination of the species as compared to the actual time course.

\section{Material and Methods}

\subsection{Seed procedure and characterization}

Seeds of Peltophorum dubium (Spreng.) Taub. var. dubium (hereafter referred to as $P$. dubium) were obtained from distinct producers between May 2011 and March 2012 from four locations: Porto Velho (PVH, RO - Brazil, $8^{\circ} 45^{\prime} \mathrm{S}, 63^{\circ} 52^{\prime} \mathrm{W}$ ); Porto Ferreira (PFR, SP - Brazil, $21^{\circ} 51^{\prime} \mathrm{S}, 47^{\circ} 25^{\prime} \mathrm{W}$ ); Apucarana (APC, PR - Brazil, $23^{\circ} 33^{\prime}$ 'S, 51 ${ }^{\circ} 27^{\prime} \mathrm{W}$ ); and Santa Maria (SMA, RS - Brazil, $\left.29^{\circ} 41^{\prime} \mathrm{S}, 53^{\circ} 49^{\prime} \mathrm{W}\right)$. Mature seeds were sampled directly from several trees per site and were characterized their weight, size and water content (Andrade, 2013). A germination test with scarified seeds at constant $25^{\circ} \mathrm{C}$ was performed in order to obtain initial values for seed viability and germination rate before the assays under fluctuating temperatures. Another control was performed after the assays to be sure they did not lose viability during the time of greenhouse experiments.

\subsection{Germination assays under greenhouse conditions}

Germination assays were carried out in aluminum sheet trays filled with commercial substrate Plantmax ${ }^{\circledR}$ and vermiculite in the proportion 1:1. Seeds were manually scarified with sandpaper and sown in the substrate, with forty seeds per tray and five trays per seed batch. The trays were distributed at random on a bench in a greenhouse where the temperature was recorded hourly by a sensor coupled to a data logger. The substrate was kept saturated with distilled water and counts of germinated seeds were daily made for 14 days. Primary root protrusion $(>0.5 \mathrm{~cm})$ was adopted as criterion of germination. Seeds remaining by the end of the two weeks in experimental conditions 
exhibited severe signals of deterioration by fungi attack and were counted as dead.

It was considered in the present work the results from seeds sown at four different times: July 2012 (Assay I); August 2012 (Assay II); September 2012 (Assay III); and December 2012 (Assay IV). Temperature range (minimum and maximum) at the assays are shown (Table 1).

\subsection{Degree-days calculating and data analysis}

Degree-days (DD) calculations methods employed (Table 2) are roughly based on the area under the diurnal isotherms and between the cardinal temperatures. All of the methods assume that the germination rate increases linearly with temperature between the lower threshold (Tb) and the optimum temperature (To). The method referred here to as DD1 (Villa Nova et al., 1972) use the median daily temperature according to the equations: $\mathrm{DD} 1=(\mathrm{Tm}-\mathrm{Tb})+(\mathrm{TM}-\mathrm{Tm}) / 2$, when $\mathrm{Tm}>\mathrm{Tb}$; and DD1 $=(\mathrm{TM}-\mathrm{Tb})^{2} /[2 .(\mathrm{TM}-\mathrm{Tm})]$, when $\mathrm{Tm}<\mathrm{Tb}$, where $\mathrm{Tm}$ and TM are the day's minimum and maximum temperatures, respectively, and $\mathrm{Tb}$ is the base temperature. The method DD2 employs the daily mean temperatures (arithmetic mean of hourly temperatures), according to the model: $\mathrm{DD} 2=[\Sigma(\mathrm{T}-\mathrm{Tb})] / 24$, where $\mathrm{T}=$ hourly temperature; if $\mathrm{T}<\mathrm{Tb} \rightarrow \mathrm{T}=\mathrm{Tb}$, and if $\mathrm{Tc} \geq \mathrm{T}>\mathrm{To}$, the expression [(To- $\mathrm{Tb})$. (Tc-T) $] /(\mathrm{Tc}-\mathrm{To}$ ) substitute for (T-Tb) in the model. Finally, method DD3 is based on the trapezoid area under the isotherms and it assumes that no degree-days accumulation occurs at temperatures below $\mathrm{Tb}$ and above Tc. DD3 were estimated according to the formulae $\left\{\left[\left(\mathrm{T}_{\mathrm{i}}-\mathrm{Tb}\right)+\left(\mathrm{T}_{\mathrm{i}+1}-\mathrm{Tb}\right)\right] / 2\right\}\left(\mathrm{t}_{\mathrm{i}+1}-\mathrm{t}_{\mathrm{i}}\right)$, where $T_{i}$ is the temperature at time $t_{i}$.

The procedure was to determine the cumulative degree-days accumulation over the 14-day assay period from the temperature data recorded in the greenhouse and the cardinal temperatures assumed for each seed population: 12.5 (Tb), 30 (To) and $38{ }^{\circ} \mathrm{C}(\mathrm{Tc})$ for PVH; 11.4, 30 and $38^{\circ} \mathrm{C}$ for PFR; $11.5,30$ and $38^{\circ} \mathrm{C}$ for APC; $11.4,29$ and $34{ }^{\circ} \mathrm{C}$ for SMA (Andrade, 2013). The number of germinated seeds was recorded daily and cumulative germination percentage was plotted on a thermal time (degree-days) scale. Then, the expected germination times were obtained from the following equation based on Garcia-Huidobro et al. (1982): $\mathrm{DD}_{i}=\left(\mathrm{T}_{\mathrm{i}}-\mathrm{Tb}\right) . \mathrm{t}_{\mathrm{i}}, \rightarrow \mathrm{t}_{\mathrm{i}}=\mathrm{DD}_{\mathrm{i}} /\left(\mathrm{T}_{\mathrm{i}}-\mathrm{Tb}\right)$, where $\mathrm{DD}_{\mathrm{i}}$ is the cumulative degree-days at the $i^{\text {th }}$ day from the start of the assay, $\mathrm{T}_{\mathrm{i}}$ is the median or mean temperature at the $\mathrm{i}^{\text {th }}$ day, and $\mathrm{t}_{\mathrm{i}}$ is the expected time corresponding to the $\mathrm{i}^{\text {th }}$ calendar day from sowing.

Cumulative germination percentages were transformed on probit scale (which linearizes a cumulative normal distribution) and regressed against log of degree-days or calendar days, and the regression lines were compared through one-way Anova (Sokal and Rohlf, 1995) followed by Tukey test, $\alpha=0.05$.

\section{Results}

In Figure 1, the germination time courses of seeds sowed at different times (Assays I, II, III and IV) are displayed, both in clock time (graphics in the left column) and thermal time scale calculated according to the method DD1 (right column). Seeds from different provenances did not differ in final germination percentage (germinability) in the greenhouse, except in Assay IV (Figure 1g) where the germination of Porto Velho (PVH) seeds was lower than that observed for other populations $(\mathrm{p}<0.05)$. Otherwise, the time required for $50 \%$ of the seeds to germinate $\left(\mathrm{t}_{50}\right)$ was higher for the PVH lot as compared to other seed

Table 1. Minimum, mean and maximum daily temperatures (mean \pm SE) during each germination assay with different Peltophorum dubium populations.

\begin{tabular}{ccccc}
\hline Assay & Month & $\begin{array}{c}\text { Minimum temperature } \\
\left({ }^{\circ} \mathbf{C}\right)\end{array}$ & $\begin{array}{c}\text { Mean } \\
\text { temperature }\left({ }^{\circ} \mathbf{C}\right)\end{array}$ & $\begin{array}{c}\text { Maximum temperature } \\
\left({ }^{\circ} \mathbf{C}\right)\end{array}$ \\
\hline I & July & $12.5 \pm 0.8$ & $20.4 \pm 0.6$ & $33.1 \pm 0.7$ \\
II & August & $13.7 \pm 0.2$ & $21.5 \pm 0.1$ & $32.3 \pm 0.2$ \\
III & September & $13.9 \pm 0.7$ & $23.2 \pm 0.5$ & $35.5 \pm 0.7$ \\
IV & December & $20.9 \pm 0.2$ & $24.8 \pm 0.4$ & $33.1 \pm 1.7$ \\
\hline
\end{tabular}

Table 2. Degree-days calculation methods used for estimate thermal time accumulation during germination assays in greenhouse.

\begin{tabular}{|c|c|c|}
\hline Method & Formulae & Constraints \\
\hline DD1 & $(\mathrm{Tm}-\mathrm{Tb})+(\mathrm{TM}-\mathrm{Tm}) / 2$ & $\begin{array}{c}\text { If } \mathrm{Tm}<\mathrm{Tb}: \\
\text { DD1 }=(\mathrm{TM}-\mathrm{Tb})^{2} /[2 .(\mathrm{TM}-\mathrm{Tm})]\end{array}$ \\
\hline DD2 & $\Sigma(\mathrm{T}-\mathrm{Tb}) / 24$ & $\begin{array}{c}\text { If } \mathrm{T}<\mathrm{Tb} \rightarrow \mathrm{T}=\mathrm{Tb} \\
\text { If } \mathrm{To}<\mathrm{T} \leq \mathrm{Tc}: \\
(\mathrm{T}-\mathrm{Tb}) \Rightarrow[(\mathrm{To}-\mathrm{Tb}) .(\mathrm{Tc}-\mathrm{T})] /(\mathrm{Tc}-\mathrm{To})\end{array}$ \\
\hline
\end{tabular}

DD1 = Method using median daily temperatures; DD2 = Method using daily mean temperatures; DD3 = Method using trapezoid area. $\mathrm{Tm}=$ day's minimum temperature; $\mathrm{TM}=$ day's maximum temperature; $\mathrm{T}=$ mean hourly temperature of the day; $\mathrm{T}_{\mathrm{i}}=$ temperature at time $\mathrm{t}_{\mathrm{i}} ; \mathrm{Tb}=$ base temperature; $\mathrm{To}=$ optimal temperature; $\mathrm{Tc}=$ ceiling temperature. 

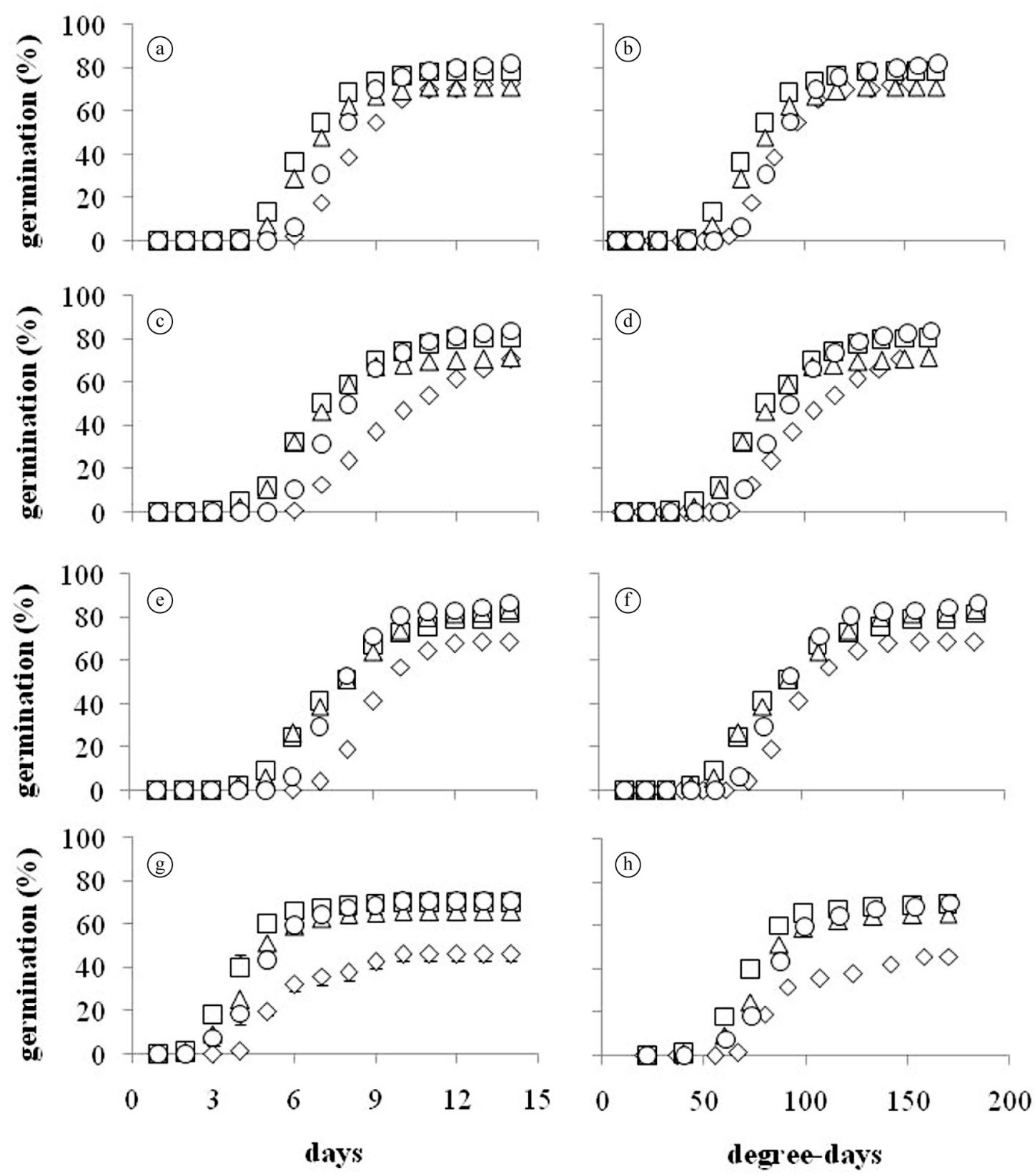

Figure 1. Germination of Peltophorum dubium seeds from Porto Velho (diamonds), Porto Ferreira (circles), Apucarana (squares) and Santa Maria (triangles), sown in July (a, b), August (c, d), September (e, f) and December (g, h). Data presented in calendar day (left column) and degree-days (right column) scale.

populations in the assays II, III and IV $(\mathrm{p}<0.05)$. The same pattern is observed when the germination curves are expressed in degree-days $(\theta)$ scale, except in the assay III, where the values for $50 \%$ germination $\left(\theta_{50}\right)$ were similar among the different seed provenances $(\mathrm{p}<0.05)$. When the assays were compared it was observed that, with exception of the Porto Velho batch in which the assays did not differ to each other, $\mathrm{t}_{50}$ values were lower in the assay IV. Otherwise, when the germination curves were expressed in degree-days, $\theta_{50}$ values concerning
APC, SMA and PFR populations were similar among the assays, whereas in the PVH batch the assay IV presented the highest $\theta_{50}$ as compared to others.

When different methods of estimation of degree-days are compared, it is was observed that, in general, the method DD1 tend to overestimate the amount of degree-days required for $50 \%$ of the seeds to germinate $\left(\theta_{50}\right)$ in comparison with other methods used, regardless of the seed provenance or the time at which the assays were performed (Figure 2). Otherwise, the method DD2 tends to underestimate $\theta_{50}$ 


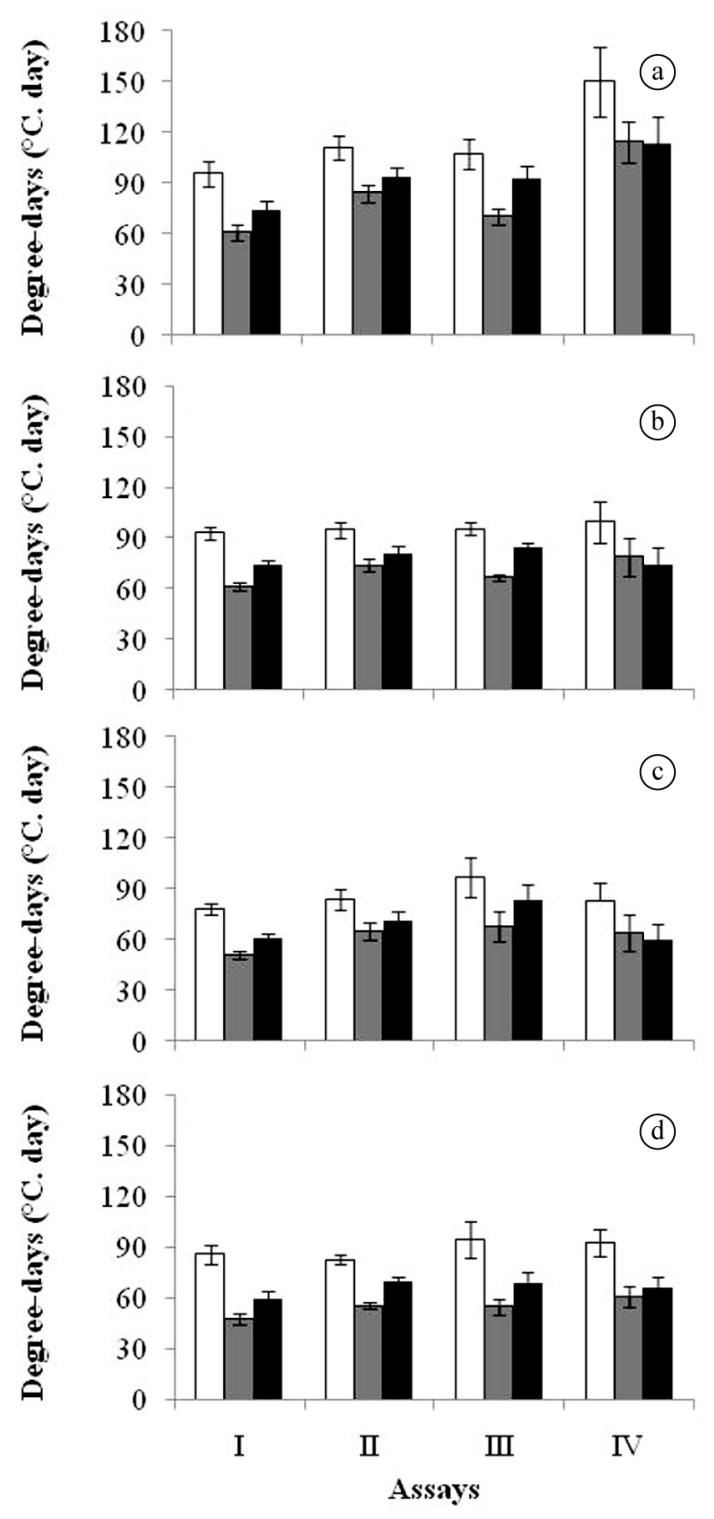

Figure 2. Degree-days for $50 \%$ germination of Porto Velho (a), Porto Ferreira (b), Apucarana (c) and Santa Maria (d) populations of Peltophorum dubium seeds sown in July (Assay I), August (Assay II), September (Assay III) and December (Assay IV). Degree-days values calculated from method DD1 (white bars), DD2 (grey bars) and DD3 (black bars), $\pm \mathrm{SE}$.

as compared to DD1, whereas $\theta_{50}$ values obtained from DD3are in general between DD1 and DD2. Based on $\theta_{50}$ criterion and taking into account all the degree-days methods used herein, in general no difference $(p<0.05)$ could be observed among trials for seed collected in Santa Maria (SMA) (Figure 2d) and Porto Ferreira (PFR) (Figure 2b), whereas for the Apucarana (APC) (Figure 2c) and Porto Velho (Figure 2a) seed batches, $\theta_{50}$ was higher in assays III (seeds sown in September) and IV (December), respectively $(\mathrm{p}<0.05)$. When compared within the assays, the $\theta_{50}$ requirements for PVH seed batch were higher than others in the assays II and IV, whereas in the assays I and III the differences where less pronounced. The $\theta_{50}$ requirements for PVH keep higher than other populations regardless of the degree-days calculation method used.

Figure 3 exhibits the time for $50 \%$ of the seeds to germinate $\left(t_{50}\right)$, estimated from the different degree-days calculation methods, in comparison with observed $t_{50}$ calculated by interpolation in the germination time courses shown in Figure 1. Concerning the seeds from APC (Figure 3c), in assay I DD1 overestimated $t_{50}$ whereas both DD2 and DD3 methods underestimated the time for $50 \%$ of the seeds to germinate in comparison with observed values. In assay III, $t_{50}$ obtained from DD2 method were significantly lower than observed $t_{50}$, whereas in trials II and IV, DD1 yielded higher $t_{50}$ than that observed. In the PVH batch (Figure 3a), regardless of assay time, $t_{50}$ estimated from DD1 method did not differ from observed values, whereas DD2 produced lower estimates of $\mathrm{t}_{50}$ in assays I, II and III. Differently from other seed collections, no difference among expected and observed $t_{50}$ values were observed for PVH seeds in assay IV. For SMA lot (Figure 3d), DD2 and DD3 methods underestimated $t_{50}$ in assays I and III, whereas in assay IV the expected $t_{50}$ calculated from DD1 was higher than observed $t_{50}$. No differences were observed among $t_{50}$ values in assay II (Figure 3c). The results from comparison within PFR lot (Figure 3b) show that in assays I, II and IV, DD1 overestimated $t_{50}$, whereas $t_{50}$ values estimated from DD2 and DD3 methods were lower than observed $\mathrm{t}_{50}$ in assays I and III.

\section{Discussion}

Germination percentage of $P$. dubium seeds from different provenances was similar to each other in the assays carried out in July (assay I), August (assay II) and September (assay III), whereas the germination percentage of the PVH seed batch was lower than others in the assay IV performed in December, at higher mean temperatures as compared to previous assays. The germination rate, taken as the reciprocal of the time for $50 \%$ germination $\left(\mathrm{t}_{50}\right)$, was also lower in the PVH batch than in others, chiefly in assay IV. Although the number of populations used here is insufficient to discuss a possible correlation between germination temperature-dependence and the geographical distribution of $P$. dubium, we expected seeds matured in warmer regions ( $\mathrm{PVH}$ batch) to respond better to increasing temperatures throughout the assays in comparison with seeds from more southern populations (PFR, APC and SMA) matured under relatively cool temperatures (Thompson, 1973). Otherwise, considering that at the end of the assay IV most of the PVH seeds presented visible signs of deterioration, it is suggested that scarification had affected the seed viability from the PVH batch, since the testa protects the embryo against adverse environmental conditions (Debeaujon et al., 2000), such as high temperatures. 

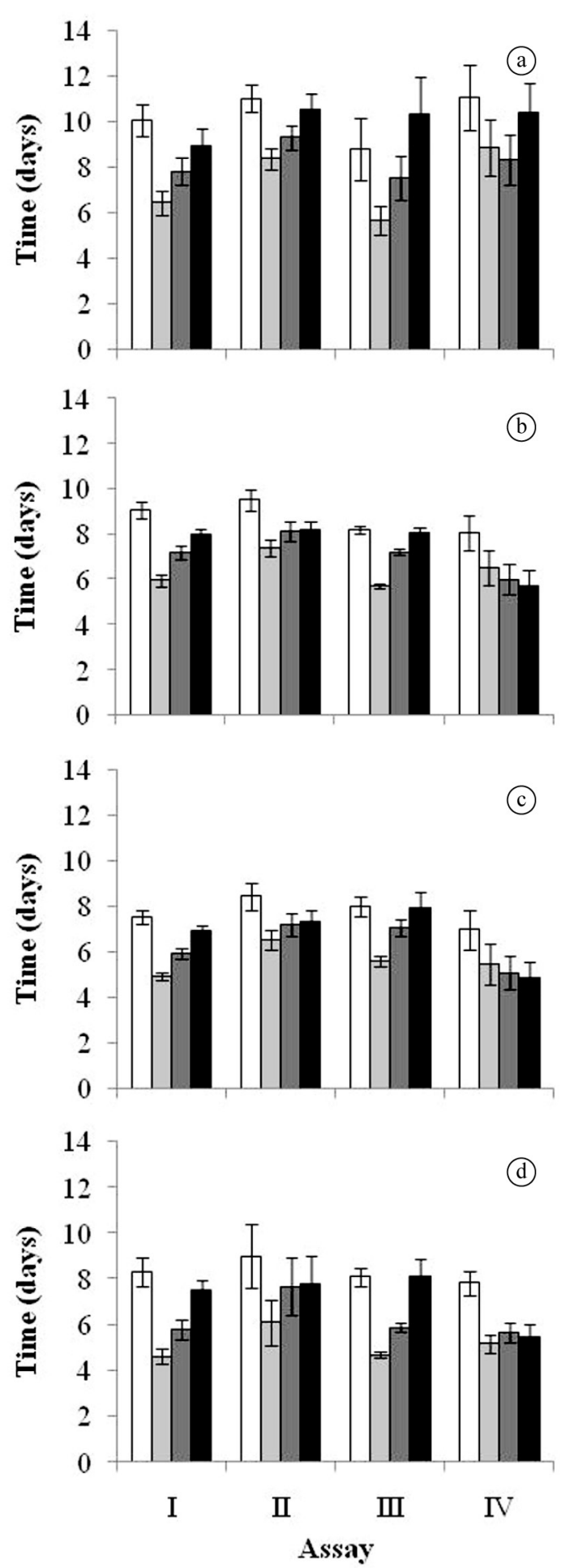

Figure 3. Time (days) for $50 \%$ germination of Porto Velho (a), Porto Ferreira (b), Apucarana (c) and Santa Maria (d) populations of Peltophorum dubium seeds sown in July (Assay I), August (Assay II), September (Assay III) and December (Assay IV). Expected times calculated from method DD1 (white bars), DD2 (light grey bars) and DD3 (dark grey bars) are compared to observed times (black bars), $\pm \mathrm{SE}$.
In spite of the relatively low base temperature $(\mathrm{Tb})$ variation among the populations (Andrade, 2013), when germination time courses of $P$. dubium seeds are plotted on a degree-days scale, the curves from different populations are closer. In the assay IV, the thermal time requirement for fifty percent of the seeds to germinate $\left(\theta_{50}\right)$ was higher in the PVH batch than in others, suggesting that higher average temperatures recorded in this assay may have negatively influenced seed germination.

When $\theta_{50}$ from different assays were compared, no difference was observed among the assays for SMA and PFR populations, whereas seeds from APC and PVH sowed in September (assay III) and December (assay IV), respectively, required more $\theta_{50}$ than in other assays. Considering that the thermal time model employed $-\theta_{\mathrm{T}}=(\mathrm{T}-\mathrm{Tb}) . \mathrm{t}_{\mathrm{g}}$ - assumes that the heat sum or thermal time $\left(\theta_{\mathrm{T}}\right)$ to germination of a given percentage remains constant (Garcia-Huidobro et al., 1982), an increase in temperature, as observed in the assay $\mathrm{IV}$, necessarily leads to a decrease of $\mathrm{t}_{\mathrm{g}}$ (time to germination of a specific percentage $g$ ). Thus, it was expected that $\theta_{50}$ did not vary with thermal conditions during the experiment, but that did not occur in P. dubium seeds from APC and, chiefly, PVH lots.

Comparing the three methods used to estimate degree-days, it was observed that, regardless of the population and the sowing time, the method described by Villa Nova et al. (1972) - here referred to as DD1 - which estimates were based in daily minimum and maximum temperatures overestimated $\theta_{50}$, whereas the method based on Arnold (1959) (DD2), which estimates took into account the differences between the temperatures taken hourly and $\mathrm{Tb}$, tended to underestimate $\theta_{50}$. Souza et al. (2011) estimated the annual degree-days availability for cane sugar in Botucatu (SP), and observed that a DD2 similar method using the averages calculated from daily maximum and minimum temperatures produced estimations of degree-days accumulation similar to those obtained from Villa Nova et al. (1972) method. Furthermore, when the authors used integration methods from temperatures taken hourly the lowest estimates of degree-days accumulation were obtained, as reported in the present study.

The models were evaluated by comparing the $\mathrm{t}_{50}$ (time to $50 \%$ per cent of the seeds to germinate) values obtained from the curves generated by models with $t_{50}$ obtained directly from the germination time courses, and it was observed that the efficiency of the method in describing the germination varied according the lot and sowing time. For example, for the experiments conducted in August (assay II) and December (assay IV) the DD3 method was adequate to describe the germination of all the batches, whereas for the assay performed in September (assay III) the DD1 method showed the best results. Considering the seed lots and sowing time, the trapezoid area method was relatively more effective in describing the germination, followed by the Villa Nova et al. (1972) method.

The germination of $P$. dubium seeds in response to temperature can vary depending on the seed provenance and the lot (Oliveira et al., 2008). Accordingly, the precise 
definition of the cardinal temperatures for each seed batch and the description of the germination in degree-days scale allow the germination time courses from different seed populations to be compared across a range of temperatures, as well as it allows a good estimate of the time to germination of specific batches based upon actual thermal environment.

In the present work, the degree-days estimated directly from temperature records schedules can serve as a basis for the expression of temperature dependence on the germination of $P$. dubium seeds from different sources in a thermal time scale, in which the germination curves from different seed populations tend to be more clustered, suggesting little variation among thermal time requirements in different populations, since there is no reduction in seed viability along time. Concerning PVH batch, a decrease in germination percentage and germination rate was observed when sowed in December (five months after the first trial), whose average temperatures were higher as compared to previous assays. Such a decrease in germination rate or, in other words, an increased requirement for thermal time (degree-days) (Cardoso, 2011) could be related to the seed viability, which is related to the physiological status of the seeds. This relationship between physiological state of the seeds and thermal time requirement has been shown for species such as Lithospermum arvense (Chantre et al., 2009). However, in the case of P. dubium seeds from PVH, the increase in $\theta_{\mathrm{T}}$ requirement when the assays were performed later in the year, with higher mean temperatures, can be related to a thermal effect on the germination of scarified seeds and not to a decrease in seed vigor caused by storage time, since the germination of seeds stored refrigerated at $5^{\circ} \mathrm{C}$ remain high even after two years (personal observation).

In conclusion, thermal time requirement for germination of $P$. dubium seeds under semi-controlled conditions can vary depending on the time of sowing, although relatively little variation could be observed in thermal time requirements during germination assays among different populations. Further experiments are warranted to test the relationship between seed vigor and germination of $P$. dubium and accumulation of thermal time during seed maturation, assessing the temperature effect during seed development on the physiological quality of the seeds.

\section{Acknowledgements}

The authors would like to thank the professors Massanori Takaki and L. Patrícia Morellato for helping with the data loggers for greenhouse experiments. LFD. was supported by CAPES and VJMC. was CNPq fellow during this research.

\section{References}

ALVARADO, V. and BRADFORD, K.J., 2002. A hydrothermal time model explains the cardinal temperatures for seed germination. Plant, Cell \& Environment, vol. 25, no. 8, pp. 1061-1069. http:// dx.doi.org/10.1046/j.1365-3040.2002.00894.x.
ALVES, E.U., GUEDES, R.S., GONÇALVES, E.P., VIANA, J.S., SANTOS, S.S. and MOURA, M.F., 2011. Effect of temperature and substrate on germination of Peltophorum dubium (Sprengel) Taubert seeds. Acta Scientiarum. Biological Sciences, vol. 33, no. 1 , pp. $113-118$

ANDRADE, L.F.D., 2013 [viewed 1 July 2014]. Características biométricas das sementes e descrição da resposta germinativa pelo modelo do tempo térmico em diferentes populações de Peltophorum dubium (Spreng) Taub. Rio Claro: Universidade Estadual Paulista, 65 p. Dissertação de Mestrado em Ciências Biológicas (Biologia Vegetal). Available from: http://base. repositorio.unesp.br/handle/unesp/87893

ARNOLD, C.Y., 1959. The determination and significance of the base temperature in a linear heat unit system. Proceedings of the American Society for Horticultural Science, vol. 74, pp. 430-445.

BARNEBY, R.C., 1996. Neotropical Fabales at NY: asides and oversights. Brittonia, vol. 48, no. 2, pp. 174-187. http://dx.doi. org/10.2307/2807811.

BEWLEY, J.D., BRADFORD, K.J., HILHORST, H.W.M. and NONOGAKI, H., 2013. Seeds: physiology of development, germination and dormancy. 3rd ed. New York: Springer. pp. 299-239.

BRADFORD, K., 2002. Applications of hydrothermal time to quantifying and modeling seed germination and dormancy. Weed Science, vol. 50, no. 2, pp. 248-260. http://dx.doi.org/10.1614/00431745(2002)050[0248:AOHTTQ]2.0.CO;2.

CARDOSO, V.J.M., 2011. Metodologia para análise da dependência térmica da germinação pelo modelo de graus-dia. Oecologia Australis, vol. 15, no. 2, pp. 236-248. http://dx.doi.org/10.4257/ oeco.2011.1502.04.

CHANTRE, G.R., BATLLA, D., SABBATINI, M.R. and ORIOLI, G., 2009. Germination parameterization and development of an after-ripening thermal-time model for primary dormancy release of Lithospermum arvense seeds. Annals of Botany, vol. 103, no. 8, pp. 1291-1301. http://dx.doi.org/10.1093/aob/mcp070. PMid:19332426.

DEBEAUJON, I., LÉON-KLOOSTERZIEL, K.M. and KOORNNEEF, M., 2000. Influence of the testa on seed dormancy, germination and longevity in Arabidopsis. Plant Physiology, vol. 122, no. 2, pp. 403-413. http://dx.doi.org/10.1104/pp.122.2.403. PMid:10677433.

GARCIA-HUIDOBRO, J., MONTEITH, J.L. and SQUIRE, G.R., 1982. Time, temperature and germination of pearl millet (Pennisetum typhoydes). Journal of Experimental Botany, vol. 33, no. 2, pp. 288-296. http://dx.doi.org/10.1093/jxb/33.2.288.

LAMARCA, E.V., PRATAVIERA, J.S.P., BORGES, I.F., DELGADO, L.F., TEIXEIRA, C.C., CAMARGO, M.B.P., FARIA, J.M.R. and BARBEDO, C.J., 2013. Maturation of Eugenia pyriformis seeds under different hydric and thermal conditions. Annals of the Brazilian Academy of Sciences, vol. 85, no. 1, pp. 223-233. http:// dx.doi.org/10.1590/S0001-37652013005000006. PMid:23460438.

LAMARCA, E.V., SILVA, C.V. and BARBEDO, C.J., 2011. Limites térmicos para a germinação em função da origem de sementes de espécies de Eugenia (Myrtaceae) nativas do Brasil. Acta Botanica Brasílica, vol. 25, no. 2, pp. 293-300. http://dx.doi. org/10.1590/S0102-33062011000200005.

MOLES, A.T., PERKINS, S.E., LAFFAN, S.W., FLORESMORENO, H., AWASTHY, M., TINDALL, M.L., SACK, L., PITMAN, A., KATTGE, J., AARSSEN, L.W., ANAND, M., BAHN, 
M., BLONDER, B., CAVENDER-BARES, J., CORNELISSEN, J.H.C., CORNWELL, W.K., DÍAZ, S., DICKIE, J.B., FRESCHET, G.T., GRIFFITHS, J.G., GUTIERREZ, A.G., HEMMINGS, F.A., HICKLER, T., HITCHCOCK, T.D., KEIGHERY, M., KLEYER, M., KUROKAWA, H., LEISHMAN, M.R., LIU, K., NIINEMETS, Ü., ONIPCHENKO, V., ONODA, Y., PENUELAS, J., PILLAR, V.D., REICH, P.B., SHIODERA, S., SIEFERT, A., SOSINSKI, E.E. Jr., SOUDZILOVSKAIA, N.A., SWAINE, E.K., SWENSON, N.G., VAN BODEGOM, P.M., WARMAN, L., WEIHER, E., WRIGHT, I.J., ZHANG, H., ZOBEL, M. and BONSER, S.P., 2014. Which is a better predictor of plant traits: temperature or precipitation? Journal of Vegetation Science, vol. 25, no. 5, pp. 1167-1180. http://dx.doi.org/10.1111/jvs.12190.

MILLER, P., LANIER, W. and BRANDT, S., 2001 [viewed 1 July 2014]. Using growing degree-days to predict plant stages. MT200103 AG7/2001. Bozeman: Montana State University Extension Service. 8 p. Available from: http://msuextension. org/publications/AgandNaturalResources/MT200103AG.pdf

OLIVEIRA, L.M., DAVIDE, A.C. and CARVALHO, M.L.M., 2008. Teste de germinação de sementes de Peltophorum dubium (Sprengel) Taubert - Fabaceae. Floresta, Curitiba, PR, vol. 38, no. 3, pp. 545-551.

SIMÃO, E., TAKAKI, M. and CARDOSO, V.J.M., 2010. Germination response of Hylocereus setaceus (Salm-Dych ex DC.) Ralf Bauer (Cactaceae) seeds to temperature and reduced water potentials. Brazilian Journal of Biology $=$ Revista Brasileira de
Biologia, vol. 70, no. 1, pp. 135-144. http://dx.doi.org/10.1590/ S1519-69842010000100019. PMid:20231970.

SOKAL, R.R. and ROHLF, F.J., 1995. Biometry: the principles and practice of statistics in biological research. 3rd ed. New York: W.H. Freeman. 887 p.

SOUZA, A.P., RAMOS, C.M.C., LIMA, A.D., FLORENTINO, H.O. and ESCOBEDO, J.F., 2011. Comparison of methodologies for degree-day estimation using numerical methods. Acta Scientiarum. Agronomy, vol. 33, no. 3, pp. 391-400. http://dx.doi.org/10.4025/ actasciagron.v33i3.6018.

THOMPSON, P.A., 1973. Geographical adaptation of seeds. In: W. HEYDECKER. Seed Ecology. London: Butterworths, pp. 31-58.

TRENTIN, R., SCHREIBER, F., STRECK, N.A. and BURIOL, G.A., 2008. Soma térmica de subperíodos do desenvolvimento da planta de melancia. Ciência Rural. Santa Maria, vol. 38, no. 9, pp. 2464-2470. http://dx.doi.org/10.1590/S0103-84782008000900008.

UC-IPM, 2014 [viewed 1 July 2014]. About degree-days [online]. Davis: University of California Agriculture and Natural Resources. Available from: http://www.ipm.ucdavis.edu/WEATHER/ ddconcepts.html

VILLA NOVA, N.A., PEDRO JR, M.J., PEREIRA, A.R. and OMETTO, J.C., 1972. Estimativa de graus-dia acumulados acima de qualquer temperatura base, em função das temperaturas máxima e mínima. Caderno de Ciências da Terra, vol. 30, 8 p. 